\title{
Effect of fermentation on mixed rumen contents and jackfruit peel using Aspergillus oryzae on in vitro gas production and digestibility
}

\author{
Mashudi Mashudi ${ }^{1 *}$, and Wahyuni Nurmawati ${ }^{1}$ \\ ${ }^{1}$ Faculty of Animal Science, Universitas Brawijaya, Jl. Veteran, Malang 65145, Indonesia
}

\begin{abstract}
The objective of this research was to investigate the effect of Aspergillus oryzae on fermentation of mixture of rumen contents and jackfruit peel on in vitro gas production and digestibility. The method used in this study was an experiment using a randomized block design (RBD) of 4 treatments and 3 replications. The treatments including of $\mathrm{T} 0=50 \%$ rumen contents $+50 \%$ jackfruit peel, $\mathrm{T} 1=40 \%$ rumen contents $+60 \%$ jackfruit peel $+0,4 \%$ Aspergillus oryzae, $\mathrm{T} 2=30 \%$ rumen contents $+70 \%$ jackfruit peel $+0,4 \%$ Aspergillus oryzae, $\mathrm{T} 3=20 \%$ rumen contents $+80 \%$ jackfruit peel $+0,4 \%$ Aspergillus oryzae. Variables observed were gas production, dry matter digestibility (DMD), and organic matter digestibility (OMD). Data were analyzed by using Analysis of Variance (ANOVA) from Randomized Block Design, if there were significant effect between the treatments then tested with least significant different (LSD). The result showed that fermentation of mixture of rumen contents and jackfruit peel have highly significant effect $(\mathrm{P}<0.01)$ on gas production, and significant effect $(\mathrm{P}<0.05)$ on $\mathrm{DMD}$ and $\mathrm{OMD}$. Gas production, DMD and OMD of fermented mixture of rumen contents and jackfruit peel are higher than control without fermentation. It is concluded that the higher jackfruit peels the higher gas production, DMD and OMD.
\end{abstract}

\section{Introduction}

Animal husbandry is the activity of raising livestock for cultivation and business. Livestock is very important as a supplier of animal product such as meat and milk. There are three important factors in the livestock business, namely breeds, feed and rearing management.

\footnotetext{
*Corresponding author: mashudi@ub.ac.id
} 
Feed is an important factor that greatly affects livestock productivity and feed costs are the largest in livestock business. High quality of feed is feed containing high nutrients needed by livestock [1]. In ruminant farm the availability of forage is absolutely necessary. Changes in land use and climate will limit the availability of forages. Climatically Indonesia has 2 seasons, namely the rainy season and the dry season, where it is very influential on the supply of forages. In the rainy season, forage can be obtained easily, but in the dry season forage becomes scarce and difficult to obtain.

Based on this, it is necessary to find alternative feeds that contain sufficient nutrients and are abundantly available as well as lower price. Alternative feed can be obtained from waste which is generally not utilized and sometime disturbs the quality of the environment.

Two of these wastes are rumen contents derived from Slaughterhouse and jackfruit peel derived from jackfruit processing industry. Rumen contents were chosen due to their relatively high protein contents and their amino acids. [2] reported that the samples of rumen contents taken from cattle had high level of crude protein (ranged between $18.52-19.56 \%$ ). According to [3], Jackfruit peel was an alternative feed that can be used as animal feed because it contains high carbohydrate $(71.53 \%)$, but low protein. Both of these wastes can be used together as animal feed but must be processed first to increase their feeding value. One technology that can be used is fermentation technology using tape yeast or Aspergilus oryzae

This study was conducted to determine the effect of a mixture of jackfruit peel and rumen contents fermented using Aspergillus oryzae on in vitro gas production, DMD and OMD.

\section{Materials and methods}

The research was conducted at the Laboratory of Animal Nutrition, Faculty of Animal Science, Universitas Brawijaya. The materials used in the study were jackfruit peel, rumen contents, tape yeast (Aspergillus oryzae), and rumen fluid. The method used in this study was an experiment using a randomized block design (RBD) of 4 treatments and 3 replications. The treatments were $\mathrm{T} 0=50 \%$ rumen contents $+50 \%$ jackfruit peel, $\mathrm{T} 1=40 \%$ rumen contents $+60 \%$ jackfruit peel $+0,4 \%$ Aspergillus oryzae, $\mathrm{T} 2=30 \%$ rumen contents $+70 \%$ jackfruit peel $+0,4 \%$ Aspergillus oryzae, $\mathrm{T} 3=20 \%$ rumen contents $+80 \%$ jackfruit peel $+0,4 \%$ Aspergillus oryzae.

Variables measured in this study were in vitro gas production (on incubation 0,2 , 4, 8, 16, 24, 36, 48, 72 hours), Dry matter digestibility (DMD), and organic matter digestibility (OMD) from in vitro gas production residues [4] and the values of a, b and $\mathrm{c}$ are calculated by the formula [5]. Data was analysed by using Analysis of Variance (ANOVA) from Randomized Block Design, if there were significant effect between the treatments then tested with least significant different (LSD).

\section{Result and discussion}

\subsection{Nutrient content of feed ingredients and feed treatment}


The results of analysis of nutrient content of feed and treated feed (\%DM) can be seen in Table 1.

Table 1. Nutrient content of rumen content and jackfruit peel (\% DM)

\begin{tabular}{|l|l|l|l|l|l|l|}
\hline No & Feed & DM & Ash & OM & CP & CF \\
\hline $\mathbf{1}$ & Rumen content & 24,31 & 8,42 & 91,58 & 9,56 & 29,65 \\
\hline $\mathbf{2}$ & Jackfruit peel & 25,45 & 7,68 & 92,32 & 10,01 & 33,01 \\
\hline
\end{tabular}

Noted: The results of the analysis from the Laboratory of Animal Nutrition, Faculty of Animal Science, Universitas Brawijaya

Nutrient content of rumen content as in Table 1 is slightly not different as reported by [6] who reported that the rumen contents of cows about $12.50 \% \mathrm{DM}, 83.92 \% \mathrm{OM}$, $11.58 \% \mathrm{CP}$ and $24,01 \% \mathrm{CF}$. Related to the jackfruits peel, [3] reported that the nutrient content of fresh jackfruit peel consists of, 9.35\% CP, 9.3\% carbohydrates, $30.52 \% \mathrm{CF}$ and $7.31 \%$ ash. The composition of the nutrient content of the rumen contents depends on feed given to the animals.

Nutrient content of each treated feed $(\% \mathrm{DM})$ can be seen in Table 2. It can be seen that $\mathrm{CP}$ and $\mathrm{CF}$ content of treated feed is higher than control without treatment. The higher jackfruit peels the higher $\mathrm{CP}$ and $\mathrm{CF}$ content.

Table 2. Nutrient content of each treatment feed (\% DM)

\begin{tabular}{|l|c|l|l|l|l|l|}
\hline No & Treatment & DM & Ash & OM & CP & CF \\
\hline 1 & T0 & 50.41 & 16.14 & 83.86 & 9.58 & 23.59 \\
\hline 2 & T1 & 51.00 & 16.36 & 83.64 & 10.06 & 25.33 \\
\hline 3 & T2 & 48.42 & 16.78 & 83.22 & 10.40 & 29.12 \\
\hline 4 & T3 & 49.57 & 19.29 & 80.71 & 11.41 & 35.75 \\
\hline
\end{tabular}

Noted: Results of analysis from the Laboratory of Animal Nutrition, Faculty of Animal Science, Universitas Brawijaya

\subsection{In Vitro gas production}

The process of anaerobic fermentation of organic matter by rumen microbes will produce VFA and gas. The amount of gas produced indicates the amount of organic matter that can be digested in the rumen. According to [7], in vitro gas production is a parameter of rumen microbial activity in degrading feed.

The amount of gas production can be used to estimate the energy value of feed in ruminants. Average in vitro Gas Production at different incubation periods can be seen at Table 3.

The results of statistical analysis showed that there was a significant effect $(\mathrm{P}<0.01)$ on the gas production. The higher the jackfruit peel the higher gas production. This may be because jackfruit peel contains high in protein and energy. The highest value of gas production is $\mathrm{T} 3$. 
Table 3. Average in vitro gas production $(\mathrm{ml} / 500 \mathrm{mg} \mathrm{DM})$ at different incubation periods

\begin{tabular}{|l|l|l|l|l|l|l|l|l|}
\hline \multirow{2}{*}{$\begin{array}{c}\text { Treat } \\
\text { ments }\end{array}$} & \multicolumn{7}{|c|}{ Incubation Periods (hours) } \\
\cline { 2 - 9 } & $\mathbf{2}$ & $\mathbf{4}$ & $\mathbf{8}$ & $\mathbf{1 6}$ & $\mathbf{2 4}$ & $\mathbf{3 6}$ & $\mathbf{4 8}$ & $\mathbf{7 2}$ \\
\hline \multirow{2}{*}{ T0 } & $3.1 \pm$ & $5.7 \pm$ & $10.6 \pm$ & $18.4 \pm$ & $27.8 \pm 1$ & $38.7 \pm 1$ & $50.1 \pm 2$ & $57.8 \pm 2$ \\
& 1.39 & $2.02^{\mathrm{a}}$ & $4.65^{\mathrm{a}}$ & $8.83^{\mathrm{a}}$ & $4.63^{\mathrm{a}}$ & $9.65^{\mathrm{a}}$ & $4.54^{\mathrm{a}}$ & $9.24^{\mathrm{a}}$ \\
\hline \multirow{2}{*}{ T1 } & $1.9 \pm$ & $4.4 \pm$ & $9.8 \pm 5$ & $18.4 \pm$ & $29.8 \pm 9$ & $41.2 \pm 1$ & $53.1 \pm 2$ & $61.2 \pm 2$ \\
& 0.75 & $2.54^{\mathrm{b}}$ & $86^{\mathrm{a}}$ & $7.28^{\mathrm{a}}$ & $.84^{\mathrm{a}}$ & $4.89^{\mathrm{a}}$ & $0.01^{\mathrm{a}}$ & $5.60^{\mathrm{a}}$ \\
\hline \multirow{2}{*}{ T2 } & $2.8 \pm$ & $6.6 \pm$ & $14.5 \pm$ & $28.1 \pm$ & $39.8 \pm 1$ & $56.7 \pm 2$ & $78.6 \pm 1$ & $86.3 \pm 1$ \\
& 1.86 & $3.40^{\mathrm{b}}$ & $4.44^{\mathrm{b}}$ & $2.59^{\mathrm{b}}$ & $.37^{\mathrm{b}}$ & $.31^{\mathrm{b}}$ & $6.01^{\mathrm{b}}$ & $8.01^{\mathrm{b}}$ \\
\hline \multirow{2}{*}{ T3 } & $3.8 \pm$ & $7.3 \pm$ & $14.5 \pm$ & $35.2 \pm$ & $48.2 \pm 5$ & $71.3 \pm 1$ & $97.0 \pm 1$ & $109.6 \pm$ \\
& 1.76 & $1.68^{\mathrm{b}}$ & $1.17 \mathrm{~b}$ & $3.83^{\mathrm{c}}$ & $.90^{\mathrm{b}}$ & $0.43^{\mathrm{b}}$ & $4.38^{\mathrm{b}}$ & $23.29^{\mathrm{b}}$ \\
\hline
\end{tabular}

Notes: Different superscripts in the same column showed very significant differences $(\mathrm{P}<0.01)$.

Kinetics of gas production is estimated using the exponential equation described by [5] $\mathrm{p}=\mathrm{a}+\mathrm{b}\left(1-\mathrm{e}^{\mathrm{ct}}\right)$. The $\mathrm{p}$ value is the cumulative gas production at time thours, while $\mathrm{a}, \mathrm{b}$ and $\mathrm{c}$ are the exponential constants of the exponential equation.

The constant value can be interpreted as gas production from soluble fraction (a), gas production from insoluble but fermentable fraction (b) and gas formation rate (c). The $\mathrm{a}+\mathrm{b}$ value can be interpreted as the maximum gas production that can be formed during the fermentation process at time $t$. The value of $a, b$ and can be seen in Table 4.

Table 4. Parameter values a, b, and c from in vitro gas production

\begin{tabular}{|l|l|l|l|}
\hline \multirow{2}{*}{ Treatments } & \multicolumn{3}{|c|}{ Parameters } \\
\cline { 2 - 4 } & $\mathbf{a}(\mathbf{m l} / \mathbf{5 0 0} \mathbf{~ m g ~ D M ) ~}$ & $\mathbf{b}(\mathbf{m l} / \mathbf{5 0 0} \mathbf{~ m g ~ D M ) ~}$ & $\mathbf{c}(\mathbf{m l} / \mathbf{h o u r s})$ \\
\hline T0 & $0.6956 \pm 0.80$ & $84.3318 \pm 42.26$ & $0.01622 \pm 0.0016$ \\
\hline T1 & $0.0000 \pm 0.00$ & $102.8203 \pm 61.68$ & $0.01645 \pm 0.0069$ \\
\hline T2 & $0.1276 \pm 0.22$ & $182.9311 \pm 144.86$ & $0.01809 \pm 0.0127$ \\
\hline T3 & $0.3158 \pm 0.55$ & $192.3105 \pm 68.19$ & $0.01805 \pm 0.0054$ \\
\hline
\end{tabular}

Noted: Parameters a, b and c show no significant effect on that value.

The results of statistical analysis showed that there was no significant effect $(\mathrm{P}>0.05)$ on $\mathrm{a}, \mathrm{b}$ and $\mathrm{c}$ value. However, there is a tendency that the higher the jackfruit peels the value of $a, b$ and $c$ increases and the highest value is T3.

Effect of treatment, also can be seen as Graph 1, relationship between gas production of treatment feed and incubation time. 


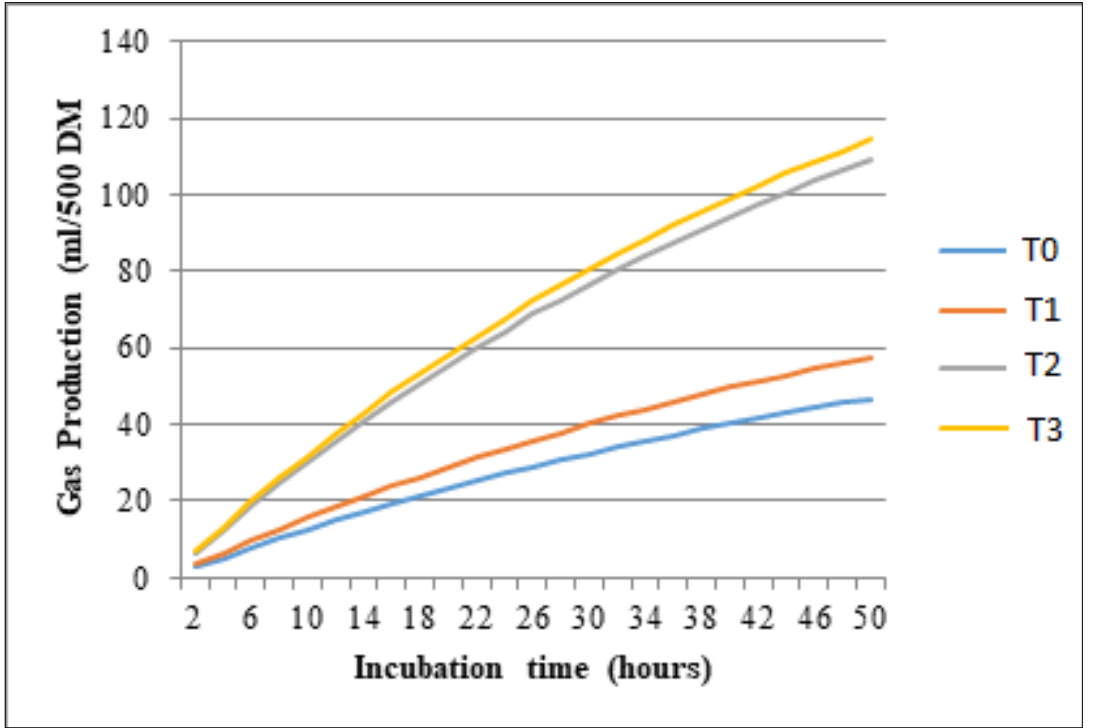

Fig. 1. Graph of the relationship between the average value of gas production from the fermented mixture of rumen contents and jackfruit skin using Aspergillus oryzae with incubation time using the $\mathrm{P}=\mathrm{a}+\mathrm{b}(1-\mathrm{e}-\mathrm{ct})$ model.

\subsection{In Vitro digestibility}

Average value of dry matter and organic matter digestibility (DMD and OMD) based on residual in vitro gas production at an incubation period of 72 hours. The average DM and OM digestibility can be seen in Table 5

Table 5. Average DMD and OMD from In Vitro Gas production residues.

\begin{tabular}{|c|c|c|}
\hline Treatments & DMD (\%) & OMD (\%) \\
\hline T0 & $39.62 \pm 2.76^{\mathrm{a}}$ & $37.05 \pm 2.80^{\mathrm{a}}$ \\
\hline T1 & $41.05 \pm 3.73^{\mathrm{a}}$ & $38.42 \pm 3.99^{\mathrm{a}}$ \\
\hline T2 & $44.45 \pm 5.00^{\mathrm{b}}$ & $42.36 \pm 5.06^{\mathrm{b}}$ \\
\hline T3 & $50.40 \pm 4.11^{\mathrm{c}}$ & $48.70 \pm 1.30^{\mathrm{c}}$ \\
\hline
\end{tabular}

Note: $*$ Different superscripts in the same column show a significant difference in effect $(\mathrm{P}<0.05)$

The results of statistical analysis showed that there was a significant effect $(\mathrm{P}<0.05)$ on the DMD and OMD. The higher the jackfruit peel the higher DMD and OMD. This may be because jackfruit peel contains high in protein and energy. The highest value Of DMD and OMD is T3. The digestibility value obtained based on in vitro gas production; therefore, the digestibility value is only the digestibility in the rumen (not including post-rumen). Low DMD and OMD values in this experiment in line with low in gas production values. 


\section{Conclusion}

The more the proportion of jackfruit peel in the fermented (using Aspergillus oryzae) mixture between jackfruit peel and rumen contents, the gas production, DMD and OMD increased. Gas production, DMD and OMD were higher in the fermented mixture between jackfruit peel and rumen contents than the unfermented control. T3 treatment is the best treatment in terms of gas production value, DMD and OMD. Further research needs to be done according to the best treatment to test the response of animals to treated feed.

\section{References}

1. P. P. Ketaren, Kebutuhan Gizi Ternak Unggas di Indonesia, 20(4): 172-180 (2010).

2. A.E. S. Moningkey, R.A.V. Tuturoong, I.D.R. Lumenta, Pemanfaatan Isi Rumen Terfermentasi Cellulomonas Sp sebagai Campuran Pakan Komplit Ternak Kelinci. Zootec, 40, 352-361 (2020).

3. S. D. Novandrini, Pengaruh Penambahan Ikan terhadap Mutu Gizi dan Penerimaan Abon Nangka, Skripsi (2003).

4. K. H. Menke, and H. Steingass, Estimation of The Energetic Feed Value Obtained from Chemical Analysis and Gas Production Using Rumen Fluid. Anim. Res. Develop. 28, 7-55 (1988).

5. E. R. Ørskov, McDonald, The Estimation of Protein Degradability in the Rumen from Incubation Measurements Weighted According to Rate of Passage. Journal of Agricultural Science, 92, 499-503 (1979).

6. R. Utomo, L. M. Yusiati, U. Umiyasih, Aryogi, Isnandar, Pemanfaatan isi Rumen Limbah Rumah Potong Hewan Sebagai Pakan Alternatif Pengganti Hijauan. Laporan Penelitian (2007).

7. I. Prihatini, S. Chuzaemi, O. Sofjan, Parameter Fermentasi Rumen dan Produksi Gas In Vitro Jerami Padi Hasil Fermentasi Inokulum Lignochloritik. Parameter Fermentasi Rumen. Jurnal Protein, 5, 24-32 (2007). 